\title{
Power Outage Sensing Device based on IOT for Service Quality Evaluation in the PLN Distribution System
}

\author{
Adryan Fahri Zul Fauzi ${ }^{1)}$, Agus Kiswantono ${ }^{2)}$, and Saidah ${ }^{3 *}$ \\ ${ }^{1,2,3)}$ Department of Electrical Engineering, Bhayangkara University, Indonesia \\ Corresponding Email: ${ }^{*}$ saidah@ubhara.ac.id
}

\begin{abstract}
In overcoming electrical disturbances, PLN implements an equipment protection system that aims to reduce the areas experiencing power outage. However, this protection system has not been integrated with the SCADA system. As a parameter to maintain customer service continuity, PLN uses customer-based indexes, i.e., the Customer Average Interruption Duration Index (CAIDI) and Customer Average Interruption Frequency Index (CAIFI). In the calculation of those index values, the record of power outage occurrence at PLN is still not accurate because the duration and frequency of power outage based on customer complaints. In this study, a Power Outage Sensing device is installed on the secondary distribution system transformer 380/220 which can ensure the location, record the frequency and duration of power outage and serve customers in real time based on IOT using WEMOS D1 and optocoupler sensors which can then be accessed on a web. In its implementation, all power outage is recorded in the database and can be accessed on the web interface. This device can speed up the recovery of disturbances in the system after an outage and perform accurate CAIDI and CAIFI index calculations as customer service evaluations.
\end{abstract}

Keyword: CAIDI, CAIFI, Optocoupler, WEMOS D1.

\section{INTRODUCTION}

PLN is a company which has the largest role in managing the electricity in Indonesia. In running the business, PLN often experiences disturbances which causes power outages. Customers as service users need guarantees on the continuity of electrical power distribution and the speed of system recovery.

In general, to determine the reliability of the system for all customers, two parameters are used, i.e., System Average Interruption Frequency Index (SAIFI) and System Average Interruption Duration Index (SAIDI). However, to determine the reliability of the system for affected customers, two parameters are used, namely the duration and frequency of power outage experienced by the customers which are expressed as Consumer Average Interruption Frequency Index (CAIFI) and Consumer Average Interruption Duration Index (CAIDI). In determining the two indexes, PLN (Persero) uses the reliability of the system in the scope of distribution process because it is the spearhead of the system that interacts directly with consumers. In connection with the above conditions, a solution is needed to find out the location, frequency, and duration of the disturbance in real time.

In the current condition, researchers [1] monitor the distribution system using Intelligent Electronic Devices (IED) or known as Supervisory Control and Data Acquisition (SCADA). However, the implementation of SCADA cannot be carried out thoroughly, especially for customers on a $380 \mathrm{~V} / 220 \mathrm{~V}$ distribution system, due to cost problems. Previous researchers [2] found an alternative device capable of detecting the location of a distribution system outage by displaying voltage and current parameters. These devices can be displayed visually with web-based media. Although this device has advantages in cost efficiency compared to existing systems, this device does not have the facility to record the duration and frequency of power outage where these two are important parameters, especially in determining the distribution system reliability index that can be used as a reference by PLN [3]. Researchers [4]-[6] have made devices to detect the locations of power outage in the distribution transformer substation area using a microcontroller [4] or using an Arduino [5]-[6] based on SAIDI and SAIFI. The power outage detection device is installed on the Low Voltage Network (LVN) with a report in the form of Short Message Service (SMS). The message received by the operator is stored in a database on the Delphi7 Software which is connected to the Maestro100 GSM modem. The stored time data is used to calculate the SAIDI and SAIFI values [6]. SAIDI and SAIFI represent the average duration and frequency of the disturbance in the system, respectively.

This study aims to produce a device that can notify the locations of disturbance in the distribution system, record the frequency, and duration of power outage experienced by customers accurately in real time based on Internet of Things (IOT). In this study, the Power Outage Sensing Device uses WEMOS D1 for IOT applications for Service Quality Evaluation of the PLN Distribution System. This tool can speed up the recovery of disturbances in the system after a power outage. In addition, the device is able to accurately determine the CAIDI and CAIFI values as a measurement of system reliability. 


\section{Methodology}

The design of power outage sensing device includes the design of hardware and software. Figure 1 is a block diagram of a power outage sensing device installed on the secondary side of the $20 \mathrm{kV}-380 \mathrm{~V} / 220 \mathrm{~V}$ distribution feeder transformer.

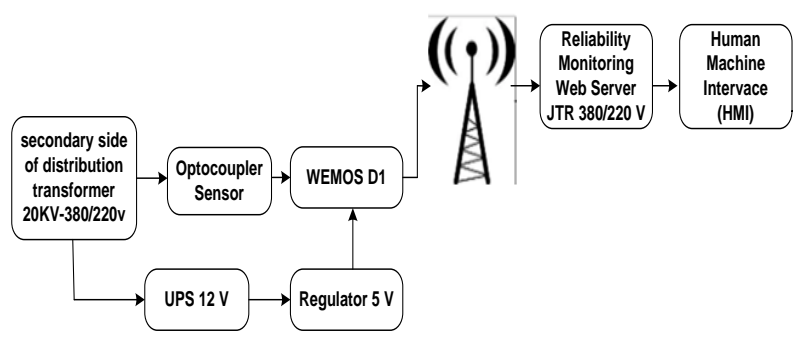

Figure 1. System Block Diagram

The following is an explanation of each block in the system:

\section{A. Sensor Circuit}

The sensor circuit consists of optocoupler sensors as transformer secondary voltage sensors and WEMOS D1 which serves as signal processing equipment and data transmitter via internet/intranet network. The sensor circuit is shown in Figure 2.

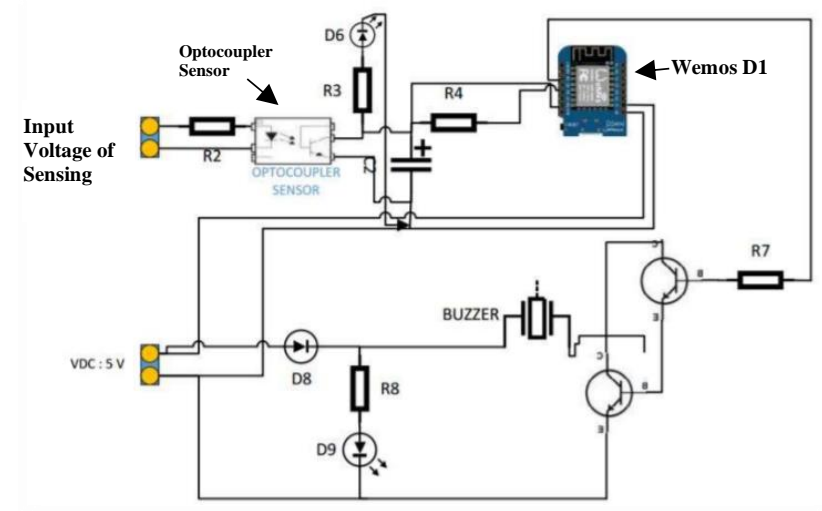

Figure 2. Optocoupler circuit and WEMOS D1

\section{B. Optocoupler}

An optocoupler is a device that is used as an electrical switch which works automatically. Basically, the optocoupler is a connecting component that works based on optical light triggers. The optocoupler in Figure 3 consists of two parts, namely:

1. A transmitter, which is an infrared LED.

2. A receiver, comprises a phototransistor component which is a transistor that is sensitive to light power.

\section{WEMOS D1}

Wemos D1 for IOT application is a wifi board based on ESP266 which is known to be economical and reliable [8]. This device can connect microcontroller devices, such as Arduino, to the internet via wifi. WEMOS D1, in Figure
4 , is a processor in a power outage sensing device, which functions to capture the voltage presence signal generated by the optocoupler sensor and send it to the server.

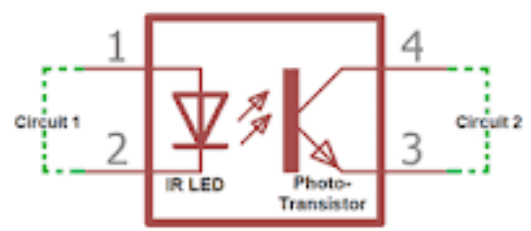

Figure 3. Optocoupler Configuration [7]

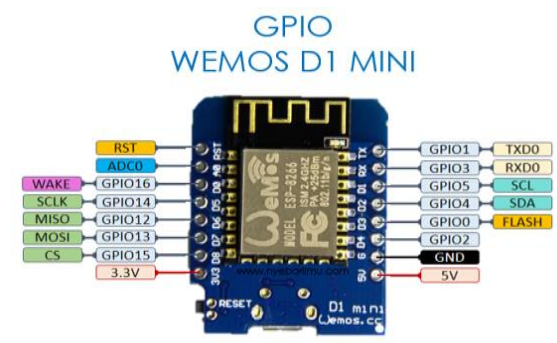

Figure 4. WEMOS D1

\section{UPS Circuit and Voltage Regulator}

Uninterruptible Power Supply (UPS) circuit in the power outage sensing device is a power supply circuit for WEMOS D1 which is connected directly from the AC voltage source PLN [9], which then goes through a rectifier and voltage regulator circuit, which also functions as an automatic charger (auto on/off based on the capacity stored in the battery). The battery is a backup supply when the PLN electricity goes out, shown in Figure 5.

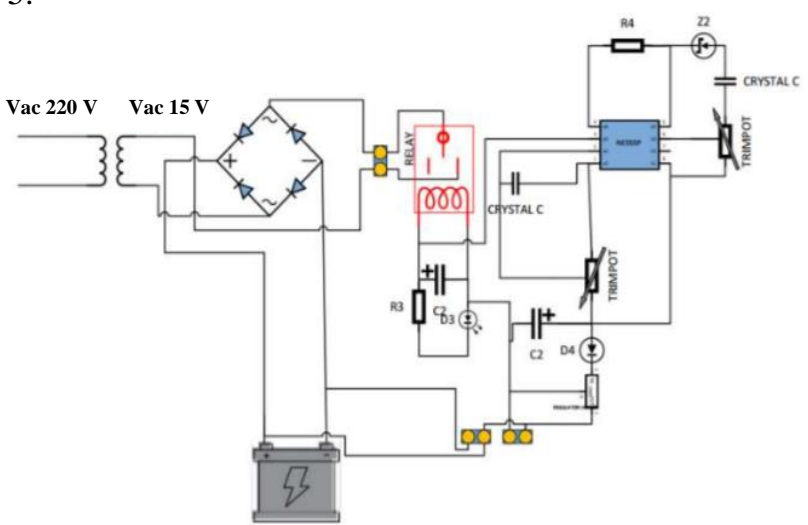

Figure 5. UPS Circuit and Voltage Regulator

\section{E. IC NE555P}

IC NE555P in Figure 6 is an electronic component that is used as a timer with monostable circuit operation and pulse generator with a stable circuit operation. 


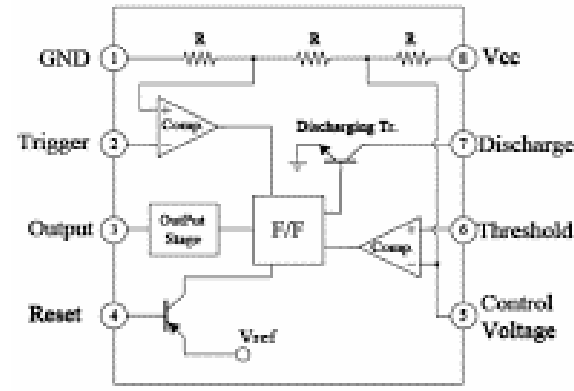

Figure 6. Pin Configuration of IC NE555P [10]

\section{F. Design of Arduino Source Code}

The programming language used in the WEMOS D1 programming as a microcontroller is the C AVR. A collection of command lines (program listings) to be written, usually saved with the extension [*.ino or *.pde] because the microcontroller used is an Arduino modulation which has its own compiler called Arduino IDE [11].

This file is then compiled and uploaded to WEMOS D1 using a USB cable so that the microcontroller can work as a system controller according to the desired performance. The design of the microcontroller software in this study aims to send a voltage signal from a secondary distribution transformer [12], to be processed and recorded by web-based system.

\section{G. Design of Database and Server}

The database serves as a place to store data sent from WEMOS D1 in the form of device addresses, initial and end time of power outage, device ID, so that the duration and frequency of power outage can be obtained. The database stores device IDs which are useful for distinguishing each sensing device installed in a scattered area. The database of this device is developed using MySQL, which is an open-source application. This power outage sensing device has 4 databases, i.e., electrical, monthly electricity, information, and user databases.

\section{H. WEB Design for Power Outage Sensing Device}

Page Home Page/Page Hypertext Processor (PHP) is a programming language that is widely used for the creation and development of a website that is embedded in HTML programming to open or read PHP programming. Apache server supports PHP by placing it as one of its modules as it makes PHP performance better.

In PHP programming, the GET function is the most commonly used function. It serves to store data that will be sent via a Uniform Resource Locator (URL). For example, to send the minute variable using the GET function, the user needs to write:

http://alamatserver/Filepemroses.php?ma=jumlahmenitawal

The time variable will be obtained in the initial duration in minutes, for example if the initial duration in minutes is 30, the URL address will be written as follows:

http://alamatserver/Filepemroses.php? $m a=30$
GET is used on CAIDI and CAIFI recording devices because it is easy to use and does not require a login or password to operate.

\section{Flowchart of Arduino Program}

Figure 7 is a flowchart of how the sensor works when a power outage occurs after the hardware functions carried out by a series of sensors, UPS, and WEMOS D1. This circuit will generate logic 1 and 0 as output which is then sent to the database wirelessly using XAMPP software. Then the logic is processed and calculated based on the CAIDI and CAIFI formulas through coding in PHP language and displayed on a web-based HMI.

There are two main parameters in recording the power outage incidents, i.e., duration and frequency. These two parameters are then used as a reference index for electricity supply companies, especially PLN [4]. The index is expressed in CAIDI, which states the average length of outage for each customer in the unit of hours/month, and CAIFI, which states how often the average power outage occurs for each customer, in the unit of times/month.



Figure 7. Flowchart of Power Outages Sensing Device

In SPLN 59 (1985), CAIDI and CAIFI are formulated as in equation (1) and (2).

$$
\begin{aligned}
& \text { CAIDI }=\frac{\sum(\text { Outage Duration in Minutes })}{\text { Total Consumers Affected }} \\
& \text { CAIFI }=\frac{\sum \text { Total Outages }}{\text { Total Consumers }}
\end{aligned}
$$




\section{RESULT AND DISCUSSION}

After the process of designing and manufacturing the power outage sensing device, testing and analysis are carried out on the optocoupler sensor circuit, UPS circuit, WEMOS D1 circuit for IOT application, and the overall power outage monitoring device circuit.

\section{A. Testing on the Optocoupler Sensor Circuit}

The implementation of this circuit test is carried out by measuring the output side of the circuit and as input to WEMOS D1 in the form of a voltage with a logic 1 (high) or 0 (low). When the PLN electricity is on, the output to Arduino has logic 0 (low) and vice versa, the output to Arduino will be logic 1 (high). Figure 8 shows the measurement points on the optocoupler circuit and the measurement results are shown in Table 1.

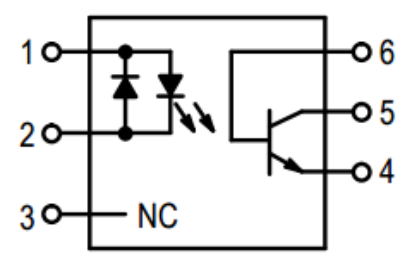

Figure 8. Measurement point on the secondary side of the transformer on the optocoupler circuit

Table 1. Results of Optocoupler Sensor Measurement

\begin{tabular}{cccc}
\hline No & $\begin{array}{c}\text { Measuring Point } \\
\text { on Optocoupler } \\
\text { Feet }\end{array}$ & $\begin{array}{c}\text { PLN } \\
\text { Status }\end{array}$ & $\begin{array}{c}\text { Rated } \\
\text { Voltage }\end{array}$ \\
\hline 1 & 1 and 2 & Connected & $220 \mathrm{~V}$ \\
\hline 2 & 5 and 4 & Connected & $\begin{array}{c}0.22 \mathrm{~V} \\
\text { (low) }\end{array}$ \\
\hline 3 & 1 and 2 & Outage & $0.00 \mathrm{~V}$ \\
\hline 4 & 5 and 4 & Outage & $\begin{array}{c}4.94 \mathrm{~V} \\
\text { (high) }\end{array}$ \\
\hline
\end{tabular}

\section{B. UPS Circuit Measurement}

This circuit is used as a power supply of equipment that will not be cut off even though the power source from PLN is cut. The UPS circuit consists of a battery, a rectifier, and an automatic charger that works to adjust the stored power (if it is full, it will be stopped, but when the battery capacity reaches a certain level, charging will be carried out). The results of the UPS circuit measurements are shown in Table 2.

Table 2. UPS circuit measurements

\begin{tabular}{cccccccccc}
\hline No & \multicolumn{1}{c}{ Measuring Point (V) } \\
\hline & 1 & 2 & 3 & 4 & 5 & 6 & 7 & 8 & 9 \\
\hline 1 & 220 & 14.8 & 13.09 & 0.0 & 4.36 & 10.0 & $\begin{array}{c}7 \\
(\text { high })\end{array}$ & 5.03 & $\begin{array}{c}0 \\
(\text { low })\end{array}$ \\
\hline 2 & 0.0 & 0.0 & 13.19 & 0.0 & 4.36 & 9.63 & $\begin{array}{c}6.9 \\
\text { (high) }\end{array}$ & 4.90 & $\begin{array}{c}0 \\
\text { (low) }\end{array}$ \\
\hline 3 & 220 & 14.7 & 10.92 & 0.0 & 3.64 & 9.1 & $\begin{array}{c}6.3 \\
\text { (high) }\end{array}$ & 4.50 & $\begin{array}{c}0 \\
(\text { low })\end{array}$ \\
\hline 4 & 0.0 & 0.0 & 10.95 & 0.0 & 3.64 & 9.0 & $\begin{array}{c}6.2 \\
\text { (high) }\end{array}$ & 4.50 & $\begin{array}{c}0 \\
(\text { low })\end{array}$ \\
\hline
\end{tabular}

\begin{tabular}{cccccccccc}
\hline No & \multicolumn{1}{c}{ Measuring Point (V) } \\
\hline 5 & 220 & 14.8 & 9.9 & 9.9 & 3.30 & 7.2 & $\begin{array}{c}9.7 \\
\text { (high) }\end{array}$ & 3.52 & $\begin{array}{c}14.1 \\
\text { (High) }\end{array}$ \\
\hline 6 & 0.0 & 0.0 & 9.9 & 0.0 & 3.30 & 6.0 & $\begin{array}{c}9.9 \\
\text { (high) }\end{array}$ & 3.00 & $\begin{array}{c}0 \\
\text { (low) }\end{array}$ \\
\hline 7 & 220 & 14.9 & 13.09 & 13.09 & 4.36 & 10.3 & $\begin{array}{c}13.09 \\
\text { (high) }\end{array}$ & 5.00 & $\begin{array}{c}14 \\
\text { (High) }\end{array}$ \\
\hline 8 & 0.0 & 0.0 & 13.1 & 0.00 & 4.36 & 6.4 & $\begin{array}{c}13.19 \\
\text { (high) }\end{array}$ & 3.05 & $\begin{array}{c}0 \\
(\text { low })\end{array}$ \\
\hline 9 & 220 & 14.9 & 13.12 & 0.00 & 4.40 & 10.20 & $\begin{array}{c}6.8 \\
\text { (high) }\end{array}$ & 5.10 & $\begin{array}{c}0 \\
(\text { low })\end{array}$ \\
\hline 10 & 0.0 & 0.0 & 13.22 & 0.00 & 4.40 & 10.25 & $\begin{array}{c}6.8 \\
\text { (high) }\end{array}$ & 5.10 & $\begin{array}{c}0 \\
(\text { low })\end{array}$ \\
\hline
\end{tabular}

Secondary Transformer PLN = 1

Secondary Trafo Power Supply $=2$

Battery $=3$

Relay Coil $=4$

Control Voltage $=5$ (PIN 5 IC NE555P)

Threshold Voltage $=6($ PIN 6 IC NE555P $)$

Reset Voltage $=7$ (PIN 4 IC NE555P)

Trigger Voltage $=8(\mathrm{PIN} 2$ IC NE555P)

Output Voltage $=9($ PIN 3 IC NE555P)

Based on measurements and tests, it was found that the calibration results (trimpot/variable resistor) of each value of $\mathrm{R} 1=6.6 \mathrm{k} \Omega$ and $\mathrm{R} 2=3.3 \mathrm{k} \Omega$ resulted in a circuit where the battery will be charged when the voltage is at the level of 9.9 Volt (charge range 9.9 Volt -13.2 Volt) and charging will stop when the battery voltage has reached 13.2 Volt (discharge range 13.2 Volt - 9.9 Volt).

Discharge is the use of battery power until the supply exceeds the load of the power outage sensing device. The values of voltage, current, and time for fully charging the battery are as shown in Table 3. The time required for recharging the battery is approximately 7 hours to reach the cut off voltage determined by the zener diode. While Table 4 states that the battery discharge time is around 5 hours.

Table 3. Battery Charging Measurement

\begin{tabular}{cccc}
\hline No & Hour & $\begin{array}{c}\text { Charger } \\
\text { Current } \\
\text { (Ampere) }\end{array}$ & $\begin{array}{c}\text { Battery Voltage } \\
\text { (Volt) }\end{array}$ \\
\hline 1 & 0 & 0.28 & $9.92 \mathrm{~V}$ \\
\hline 2 & 1 & 0.27 & $10.39 \mathrm{~V}$ \\
\hline 3 & 2 & 0.21 & $10.89 \mathrm{~V}$ \\
\hline 4 & 3 & 0.16 & $11.30 \mathrm{~V}$ \\
\hline 5 & 4 & 0.15 & $11.52 \mathrm{~V}$ \\
\hline 6 & 5 & 0.15 & $11.88 \mathrm{~V}$ \\
\hline 7 & 6 & 0.15 & $12.07 \mathrm{~V}$ \\
\hline 8 & 7 & 0 & $13.1 \mathrm{~V}$ \\
\hline
\end{tabular}

Table 4. Battery Discharging Measurement

\begin{tabular}{ccc}
\hline No & Time (hour) & $\begin{array}{c}\text { Battery Voltage } \\
\text { (Volt) }\end{array}$ \\
\hline 1 & 0 & $13.1 \mathrm{~V}$ \\
\hline 2 & 1 & $12.33 \mathrm{~V}$ \\
\hline 3 & 2 & $11.49 \mathrm{~V}$ \\
\hline 4 & 3 & $10.95 \mathrm{~V}$ \\
\hline 5 & 4 & $10.51 \mathrm{~V}$ \\
\hline 6 & 5 & $9.94 \mathrm{~V}$ \\
\hline
\end{tabular}




\section{Testing of WEMOS D1}

Testing on WEMOS D1 is carried out to determine whether the WEMOS D1 circuit is connected to the server. It is performed using Arduino IDE with ATCommand via Serial Monitor.

If the WEMOS D1 circuit does not answer "OK" then it can be interpreted that the Arduino and WEMOS D1 circuits are not connected. Based on the device testing, it can be concluded that the WEMOS D1 Circuit is properly installed.

\section{Database Testing}

Database testing aims to test the system ability to store database based on the signal sent by WEMOS D1 in the form of outage time and number of outages. The test method is by changing the length of outage and checking the result change in the database. Table 5 is the result of database testing.

Table 5. Database Testing

\begin{tabular}{cll}
$\begin{array}{c}\text { Outage } \\
\text { Duration }\end{array}$ & \multicolumn{1}{c}{ Server Database } & Match \\
\hline $\begin{array}{c}12: 29 \text { until } \\
12: 32\end{array}$ & $\begin{array}{l}\mathrm{Ma}=29, \mathrm{Mb}=32 \\
\mathrm{Ja}=12, \mathrm{Jb}=12\end{array}$ & Yes \\
\hline $\begin{array}{c}12: 33 \text { until } \\
12: 34\end{array}$ & $\mathrm{Ma}=33, \mathrm{Mb}=34$ & Yes \\
\hline $\begin{array}{c}12: 35 \text { until } \\
12: 37\end{array}$ & $\mathrm{Ma}=35, \mathrm{Jb}=12$ & \\
\hline $\begin{array}{c}12: 40 \text { until } \\
12: 44\end{array}$ & $\begin{array}{l}\mathrm{Ma}=40, \mathrm{Jb}=12 \\
\text { 12:49 until }\end{array}$ & $\mathrm{Ma}=49, \mathrm{Jb}=12$ \\
$12: 50$ & $\mathrm{Ja}=12, \mathrm{Jb}=12$ & Yes \\
\hline $\begin{array}{c}12: 55 \text { until } \\
13: 01\end{array}$ & $\mathrm{Ma}=55, \mathrm{Mb}=01$ & Yes \\
\hline $13: 04$ until & $\mathrm{Ja}=12, \mathrm{Jb}=13$ & Yes \\
$13: 10$ & $\mathrm{Ja}=13, \mathrm{Jb}=13$ & Yes \\
\hline
\end{tabular}

Based on Table 5, after testing by changing the length of outage, it can be concluded that the presentation of MySQL database storage success reaches $100 \%$.

\section{E. Testing of Overall Device}

The testing of the power outages sensing device is carried out when the entire circuit has been connected to a single circuit. When the electricity is off, WEMOS D1 will read a high value and the initial time of the outage will be recorded and the number of outages will increase. When the electricity is on, WEMOS D1 will read the low value and the time when the outage ends will be recorded and the data will be sent to the database.

The test is divided into three stages as follows:

\section{Sending WEMOS D1 data to server}

Testing of power outages sensing device is conducted based on PLN status. As seen in Table 6, data can be sent if the end time is recorded in WEMOS D1.

2. Sending data from server to database

Table 7 shows the test of data transfer to the database based on PLN status.
Table 6. Testing of Sending WEMOS D1 Data to the Server

\begin{tabular}{cccccc}
\hline $\begin{array}{c}\text { Initial } \\
\text { PLN }\end{array}$ & $\begin{array}{c}\text { Final } \\
\text { PLN } \\
\text { Status }\end{array}$ & $\begin{array}{c}\text { Start } \\
\text { Time }\end{array}$ & $\begin{array}{c}\text { End } \\
\text { Time }\end{array}$ & $\begin{array}{c}\text { Number } \\
\text { of } \\
\text { Outages }\end{array}$ & $\begin{array}{c}\text { Data } \\
\text { Delivery } \\
\text { Status to } \\
\text { Server }\end{array}$ \\
\hline $\begin{array}{c}\text { On to } \\
\text { Off }\end{array}$ & $\begin{array}{c}\text { Off to } \\
\text { On }\end{array}$ & Rec. & Rec. & Inc. & Sent \\
\hline $\begin{array}{c}\text { On to } \\
\text { Off }\end{array}$ & - & Rec. & $\begin{array}{c}\text { Not } \\
\text { Rec. }\end{array}$ & $\begin{array}{l}\text { Not } \\
\text { Inc. }\end{array}$ & $\begin{array}{c}\text { Not } \\
\text { Sent }\end{array}$ \\
\hline- & $\begin{array}{c}\text { Off to } \\
\text { On }\end{array}$ & $\begin{array}{c}\text { Not } \\
\text { Rec. }\end{array}$ & Rec. & Inc. & Sent \\
\hline $\begin{array}{c}\text { Off to } \\
\text { On }\end{array}$ & $\begin{array}{c}\text { On to } \\
\text { Off }\end{array}$ & $\begin{array}{c}\text { Not } \\
\text { Rec. }\end{array}$ & Rec. & Inc. & Sent \\
\hline
\end{tabular}

Rec. $=$ Recorded

Inc. $=$ Increase

Table 7. Testing of Data Transfer from Server to Database

\begin{tabular}{cccc}
\hline $\begin{array}{c}\text { Start } \\
\text { Time }\end{array}$ & $\begin{array}{c}\text { End } \\
\text { Time }\end{array}$ & $\begin{array}{c}\text { Number of } \\
\text { Outages }\end{array}$ & $\begin{array}{c}\text { Data Delivery } \\
\text { Status from Server } \\
\text { to Database }\end{array}$ \\
\hline $20: 42$ & $20: 44$ & Recorded & Sent \\
\hline $20: 45$ & $20: 46$ & Recorded & Sent \\
\hline- & $20: 46$ & Not Recorded & Not Sent \\
\hline $20: 50$ & $20: 55$ & Recorded & Sent \\
\hline
\end{tabular}



Figure 9. Power Outages Sensing Device

\section{Testing of real system}

The last test was testing of the power outages sensing device (Figure 9) on the PLN system which was carried out by installing the power outages sensing device on a consumer's (electricity line?) of the distribution transformer for the Taman feeder, located 
at Jalan Suningrat No 43 Ketegen Sidoarjo, for two months (March and April 2020). Then the data is compared to the outage data owned by PLN UP3 West Surabaya. The Taman feeder transformer serves 76 customers from class R1 (households), the results obtained are shown in the Table 8.

Table 8. Results of Real System Testing

\begin{tabular}{llcc}
\hline No & & March & April \\
\hline I. & $\begin{array}{l}\text { Before Installation of Power } \\
\text { Outage Sensing Device }\end{array}$ & & \\
\hline & Outage Duration (minute) & 55 & 0 \\
\hline & Number of Outage (times) & 1 & 0 \\
\hline & CAIDI Value & 55 & 0 \\
\hline CAIFI Value & 1 & 0 \\
\hline II & $\begin{array}{l}\text { After Installation of Power } \\
\text { Outage Sensing Device }\end{array}$ & & \\
\hline Outage Duration (minute) & 70 & 0 \\
\hline & Number of Outage (times) & 1 & 0 \\
\hline & CAIDI Value & 70 & 0 \\
\hline & CAIFI Value & 1 & 0 \\
\hline
\end{tabular}

The comparison of outages occurred in transformer T015 between PLN data before and after the installation of power outages sensing device, shows a difference in March for an outage occurred on March 17, 2020.

The determination of CAIDI value in March shows that in the PLN data, outages occurred for 55 minutes, while in real time the sensing device recorded 70 minutes, resulting in different CAIDI values. The 15-minute difference might be caused by the delay in response by the PLN on duty team in finding out about the power outage or delay in incoming customer reports.

CAIFI values between PLN data and sensing device did not show any difference. Because every disturbance requires a system recovery conducted by PLN. Hence, the number of outages will always be the same, between the sensing device record and manual monitoring, based on the realization pattern of the disturbance by PLN. While in April there were no outage incidents.

\section{CONCLUSION}

The power outage sensing device installed on the secondary side of the $20 \mathrm{kV}-380 \mathrm{~V} / 220 \mathrm{~V}$ distribution feed transformer can provide real time outage information without waiting for reports from customers. This device can provide information based on IOT with WEMOS D1 about the location of the outage so that the recovery time can be sped up, duration of the outage, and frequency of outages in one month. By using these parameters, the CAIDI and CAIFI values, which represent the PLN reliability index in providing services to customers, can be calculated.

\section{REFERENCES}

[1] Q. Lujin, H.O Cuijuan, JIN Huawei, LI Meng, WANG Ying, "CIM-Based Fault Detection Analysis of Distribution System". The International Conference on Advanced Power System Automation and Protection, 2011.
[2] Daniel B. Koch, "An Internet of Things Approach to Electrical Power Monitoring and Outage Reporting", IEEE 978-1-539-3/17, 2017.

[3] SPLN 59. "Keandalan Pada Sistem Distribusi 20 KV dan $6 \mathrm{KV}$ " Jakarta : Departemen Pertambangan dan Energi Perusahaan Umum Listrik Negara, 1985.

[4] Pandiana, A. S., R.Permana, "Rancang Bangun Pelaporan Padam Listrik Pada Area Gardu Trafo Distribusi Menggunakan Mikrokontroler", Tugas Akhir, Institut Teknologi Sepuluh Nopember, Surabaya, 2015.

[5] Fauzi, A.F.Zul, "Alat Pemantau Padam Listrik Untuk Penentuan Nilai Saidi Saifi Sebagai Bahan Evaluasi Kehandalan Sistem Distribusi Tenaga Listrik Berbasis Arduino Uno”, Universitas Diponegoro, Semarang, 2016.

[6] S. Yuliatri, "Alat Pelapor Padam Listrik Pada Area Gardu Trafo Distribusi Guna Menentukan Nilai Saidi Saifi Berbasis Arduino", Fakultas Vokasi Institut Teknologi Sepuluh Nopember Surabaya 2017

[7] Malvino, Albert Paul, "Prinsip-Prinsip Elektronika". Jakarta : Salemba Teknika, 2018.

[8] T.T. Saputro., "Wemos D1, Board ESP8266 Yang Kompatible Dengan Arduino" Embeddednesia. com. https://embeddednesia.com/v1/wemos-d1-boardesp8266-yang-kompatible-dengan-arduino/. 2017

[9] Prasetyo, Dery. "Fuse Cut Out Sebagai Pengaman Jaringan Distribusi Satu Fasa Di Penyulang Tambak Lorok 7 Rayon Semarang Timur" Universitas Diponegoro: tidak diterbitkan, 2014.

[10] D. Kho, "Mengenal IC 555 (IC Timer) dan Konfigurasi kakinya, Teknik Elektronika" https://teknikelektronika.com /pengertian-mengenal-ic555 - ic - timer - konfigurasi - kaki - ic555/. dilihat 26 Agustus 2019.

[11] Kadir, Abdul..”Panduan Praktis Mempelajari Aplikasi Mikrokontroller Arduino".Jakarta: Andi Publisher, 2014.

[12] Yuwono, Teguh, "Transformator. Semarang: Bahan Ajar Program Diploma III Fakultas Teknik Universitas Diponegoro". 2003. 